\title{
The Bible Retold by Jewish Artists, Writers, Composers and Filmmakers, edited by Helen Leneman and Barry Dov Walfish
}

Sheffield: Sheffield Phoenix Press, 2015 | 3 I 4 pages | ISBN: 978I-909-69793-5 (hardcover) £60.00

The Bible Retold by Jewish Artists, Writers, Composers and Filmmakers manages to be simultaneously focused and expansive. It is focused on twentieth- and twenty-

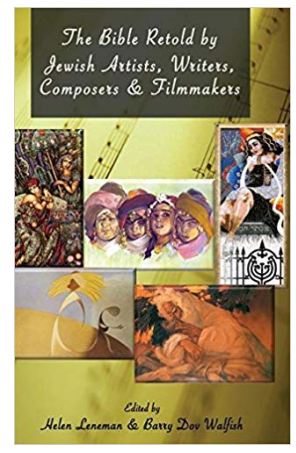
first-century Jewish artists who retell biblical texts. That focus, however, is not myopic: Yael Feldman's chapter about how the Aqedah is depicted in Israeli arts and culture places those depictions into dialogue with Christian theology, for example. And yet, I know of no other volume with such sustained reflection on Jewish receptions, so this volume is making a significant contribution to the field of reception history. That field is so vast as to be potentially unmanageable, so limiting the retellings to the past two centuries gives readers a helpful narrowing lens through which to view the broad field.

The volume is also expansive, insofar as the retellings happen through a variety of media: visual art, literature (including short stories, novels and poetry), music, and film. This variety is nicely balanced in the volume, and, as the introduction notes, it is the first book to encompass so many types of retellings (vii). The texts that are considered are also diverse, including narrative and Psalms. Some retellings are based on relatively short textual pericopes like Jacob's ladder in Gen 28:10-22, while others, such as Shalom Auslander's short story based on the plagues, retells multiple chapters in Exodus. Rather than merely fitting into a small niche, The Bible Retold is quite broadly helpful and applicable in a variety of contexts. I plan to use many of its specific examples of biblical reception in the undergraduate classroom.

The Bible Retold begins with a helpful orienting introduction, and is then divided into five sections. Part I is about biblical women and considers how they have been portrayed in visual art, poetry and music. In this section, Edna Southard examines how the artist Abel Pann (1883-1963) depicts biblical women and Lynne Swarts does the same for the artist Ephraim Moses Lilien (1874-1925). In chapter 3, Rachel Adelman analyzes modern Israeli poetry about Rachel the matriarch. Chapter 4 is Ellen Frankel's description of her process for writing the libretto for a musical piece about Hagar; this chapter includes an appendix where Andrea Clearfield describes her process 
for composing the music for the same artifact. Part II of the volume focuses on the Aqedah, and includes Yael S. Feldman's discussion in chapter 5 of how various interpretations of that topic have emphasized either "the joy of the binding" or "the fear of Isaac." In chapter 6, Nehama Aschkenasy analyzes how the Aqedah provides the scaffold and intertext throughout David Grossman's novel To the End of the Land. In chapter 7, which concludes the section on the Aqedah, Siobhán Dowling Long discusses composer Judith Lang Zaimont's version of the story in her 1986 cantata, Parable: A Tale of Abram and Isaac. Part III looks at biblical narratives in short stories. In chapter 8 Helen Leneman and Ellen Feig identify how Shalom Auslander's short story "Plagued," about Exodus, retells the biblical narrative in a satirical and transgressive manner. In chapter 9, Wendy Zierler describes how various literary appropriations of Jacob's ladder (Gen 28:IO-22) use that text to express both dreams of and critiques about contemporary Jewish life. Part IV of the volume is about Esther, and in chapter ıo, Barry Dov Walfish reviews Esther's iconography in modern Jewish art. Leneman writes in chapter I I about how two Jewish composers (Hugo Weisgall and Darius Milhaud) reimagine Esther's story in their operas. In chapter I2, Naama Harel compares Amos Gitai's 1985 film Esther with Itzik Manger's 1936 play Megile-lider (The Songs of the Megillah), noting how they both resemble Purim plays. The final section of the volume, Part V, includes two chapters on the Psalms. In chapter I 3, Max Stern and Leneman discuss Leonard Bernstein's musical juxtaposition of six psalms in his 1965 composition Chichester Psalms. This chapter includes an addendum by composer Victoria Bond, in which she describes her "motives and methods" (267) for composing a musical version of Ps 84. In chapter I4, Roberta Lander Markus reviews how the visual artist Benn (Bencjon Rabinowicz) illustrated the Psalms.

A strength of this volume is the connection between the various chapters, which allow for overlap without repetition. For example, Southard focuses on Abel Pann's art in chapter I, but Feldman also references his work in chapter 5 . The chapters which describe how music and librettos are composed (4, 7, II, and I3) are fascinating to read together for the similarities and differences in the artists' processes. Though many edited volumes might be valued for the individual chapters, The Bible Retold is one that is well worth reading as a whole.

Editors Helen Leneman and Barry Dov Walfish explain in the introduction that all of the retellings can be can be considered a form of modern 
midrash, both in the sense that the artists fill in gaps in the narrative, and that the artists draw out a contemporary significance to the meanings of the ancient biblical texts (vii). That first aspect of midrash as gap-filling appears in a number of chapters in the volume. Several artists use midrash as source material to answer textual questions and fill in textual gaps, such as Frankel, who used rabbinic midrash on Hagar to develop the persona of Hagar for her libretto, even if at times she "chose to ignore it" (74). Chapter 3, Adelman's analysis of Rachel the matriarch in modern Israeli poetry, contains one of the more sustained reflections in the volume about how these retellings are analogous to classic rabbinic midrash (56). Adelman adopts Wendy Zierler's language of "a hermeneutics of displacement" and "a hermeneutics of identification" to describe the processes engaged by female poets who write about biblical Rachel, and readers who read those poems. Adelman also draws on Joshua Levinson's observation of the dialogic tension that exists in midrash between the biblical text and the rewritten version (56). She explains that her essay "seeks to expand the definition of classical midrash" which traditionally "served as a creative means of reading meaning into the biblical text" (69). These newer expressions of midrash still appropriate the setting of the biblical world, but also jettison the limits of the traditional meanings, in order to bring new life into that world (69). In Zierler's own chapter 9, she draws on Lesleigh Cushing Stahlberg's terminology of "stance" to describe David Frischmann's Sullam Ya'aqov as taking a stance of "radical displacement" vis-à-vis Gen 28, as Frischmann removes Jacob, God, and the Land of Israel from his retelling (I79-80). Stahlberg's language is helpful here, though it might strengthen Zierler's theoretical discussion if she also included Stahlberg's other terms of "filter" and "approach" and noted how they applied to the retellings of the story of Jacob's ladder.

The second aspect of midrash, which seeks to make biblical texts relevant and applicable to current life, also occurs throughout The Bible Retold. In chapter 4, Frankel explains that Hagar was chosen as a focus in hopes that the West would take a new look at the Abrahamic narrative after the events of $9 / \mathrm{I}$; ; the hope being that there could be a deeper understanding of the lineage of the three monotheistic faiths (72). A number of the artists who live(d) in the country of Israel have been deeply affected by social and political realities of life there, and those are reflected in their retellings. For example, in chapter 5 Feldman notes how decades of wars in Israel eroded any sense of "glory" in the Aqedah. She explains, "The 1982 Lebanon War in particular exacerbated the antagonism to any sacrosanct representations 
of 'national sacrifice'" (I03). Grossman's novel, discussed by Aschkenasy in chapter 6, is framed around three major Israeli conflicts: the Six-Day War of 1967 , the 1973 Yom Kippur War, and the Second Intifada in 2000 (I 22). Grossman clarifies in the afterword to his novel that the story is tied to his personal grief over the death of his son Uri in the 2006 Second Lebanon War (I 24). Artist Abel Pann illustrated the Aqedah in the I 920 s through the I 940s, but his iconography became more personal after his son was killed in the Israeli War of Independence ( I 5 , I O2). Not only are artists retelling the biblical stories in such a way as to make them relevant to their own lives, but the retellings become a way to comment on personal experiences of anxiety, grief, and loss.

The nature of the relationship between retellings and the original stories gets clarified throughout the volume, such as when Leneman explains that the musical "Esther is not a faithful re-enactment of the biblical story, but an artistic creation based upon it" (219). Walfish makes similar comments as he reflects about the visual interpretations of Esther. For example, he notes that Lilian Broca's mosaic of Esther's Offering "deviated from the story for dramatic effect" (203), and another of Broca's images is "a scene the artist invented in order to deepen our insight into Esther's thought process and character development" (205). Walfish also writes that some of these "inventions" happen because of a felt need for information based on something lacking in the biblical text (206-7).

In chapter 8, Leneman and Feig describe Shalom Auslander's short story about the plagues as highlighting a perspective absent in the biblical text, namely, one that is sympathetic to the plight of the Egyptians. They comment, "Not only is it highlighted-Auslander seems to be rewriting the Israelite situation. There is no mention of slavery and suffering by the Israelites, which makes the suffering of the Egyptians more poignant.... Without the Pharaoh-Moses dialogues, it seems that the Egyptians are suffering the plagues for no reason" (I69). Leneman and Feig here raise the question about when a retelling becomes more of a rewriting: is it perspective? Is it when the work is not primarily gap-filling, but leaving out part of the original story? The main character in Auslander's short story understands the plagues not as miracles, but rather hocus pocus. Leneman and Feig note that though this view is common in modern times, Auslander is provocatively suggesting that there may always have been skeptics, even among those who experienced the plagues. They perhaps overstate the case when they write that Auslander "may also be forcing the modern reader to accept that the story is hocus 
pocus" (I65). It seems unlikely to me that a reception can "force" a reader "to accept" something, as evidenced by the incredible freedom readers have to read into the text whatever they want to see, and whatever confirms their understanding. Later, the language of "force" is mitigated when Leneman and Feig write that Auslander's retelling "makes the reader question ... gives the reader permission to question" (I69).

The introduction supports this idea that a reader —of the retellings, and of the biblical text-is permitted and even encouraged to question. The editors write that the chapters in the volume "will stimulate the reader to look at the texts in new ways even as they may challenge our personal or traditional interpretation of those texts" (vii). In various and varied ways, The Bible Retold inspires a re-reading of the biblical text. As the very title of this journal indicates, this is a worthy endeavor.

Sara M. Koenig

Seattle Pacific University and Seminary 